\title{
Gastrointestinal parasites of a population of emus (Dromaius novaehollandiae) in Brazil
}

\author{
S. S. M. Gallo (D), C. S. Teixeira $^{a}$ (D), N. B. Ederlib (D) and F. C. R. Oliveira ${ }^{a *}$ (D) \\ a'Laboratório de Sanidade Animal - LSA, Centro de Ciências e Tecnologias Agropecuárias - CCTA, Universidade Estadual \\ do Norte Fluminense - UENF, CEP 28035-302, Campos dos Goytacazes, RJ, Brasil \\ ${ }^{b}$ Instituto do Noroeste Fluminense de Educação Superior - INFES, Universidade Federal Fluminense - UFF, 28470-000, \\ Santo Antônio de Pádua, RJ, Brasil \\ *e-mail: oliveirafcr@gmail.com
}

Received: January 9, 2018 - Accepted: June 19, 2018 - Distributed: February 28, 2020

(With 2 figures)

\begin{abstract}
Emus are large flightless birds in the ratite group and are native to Australia. Since the mid-1980s, there has been increased interest in the captive breeding of emus for the production of leather, meat and oil. The aim of this study was to identify gastrointestinal parasites in the feces of emus Dromaius novaehollandiae from a South American scientific breeding. Fecal samples collected from 13 birds were examined by direct smears, both with and without centrifugation, as well as by the fecal flotation technique using Sheather's sugar solution. Trophozoites, cysts and oocysts of protozoa and nematode eggs were morphologically and morphometrically evaluated. Molecular analysis using PCR assays with specific primers for the genera Entamoeba, Giardia and Cryptosporidium were performed. Trophozoites and cysts of Entamoeba spp. and Giardia spp., oocysts of Eimeria spp. and Isospora dromaii, as well as eggs belonging to the Ascaridida order were found in the feces. Three animals were diagnosed with Giardia spp., and three were positive for Entamoeba spp. based on PCR techniques. After analyzing the data, we concluded that emus were infected enzootically by nematode and protozoan species.
\end{abstract}

Keywords: coccidia, helminth, protozoan, ratite.

\section{Parasitas gastrointestinais de emus Dromaius novaehollandiae de cativeiro no Brasil}

\section{Resumo}

Emus são aves grandes que não voam pertencentes ao grupo das ratitas e são originários da Austrália. Desde meados da década de 1980, aumentou o interesse pela criação de emus em cativeiro para a produção de couro, carne e óleo. O objetivo deste estudo foi identificar parasitas gastrointestinais nas fezes de emus Dromaius novaehollandiae de um criatório científico da América do Sul. Amostras de fezes coletadas de 13 aves foram examinadas por esfregaços diretos, tanto com e sem centrifugação, quanto com a técnica de flutuação fecal utilizando solução de açúcar de Sheather. Trofozoítos, cistos e oocistos de protozoários e ovos de nematóides foram avaliados morfologicamente e morfometricamente. Foram realizadas análises moleculares utilizando ensaios de PCR com primers específicos para os gêneros Entamoeba, Giardia e Cryptosporidium. Trofozoítos e cistos de Entamoeba spp. e Giardia spp., oocistos de Eimeria spp. e Isospora dromaii, bem como ovos pertencentes à ordem Ascaridida foram encontrados nas fezes. Três animais foram diagnosticados com Giardia spp., e três foram positivos para Entamoeba spp. com base em técnicas de PCR. Depois de analisar os dados, concluímos que os emus estavam infectados enzooticamente por espécies de nematóides e protozoários.

Palavras-chave: coccidio, helminto, protozoário, ratita.

\section{Introduction}

The emu Dromaius novaehollandiae is the largest bird native to Australia and the only living member of the genus Dromaius. It is the second-largest bird in the world by height, after its ratite relative, the ostrich Struthio camelus. The emu inhabits most areas of mainland Australia, with the exceptions of heavily populated areas, dense forests and arid areas (Davies, 1976).

In birds, protozoa can be found in the digestive tract (including the oropharynx, intestines and cloaca), where they are an important cause of disease, as well as in the 
bloodstream and internal organs (Silvanose et al., 1998). Protozoa commonly found in birds include Eimeria spp., Isospora spp., Sarcocystis spp., Cryptosporidium spp., Giardia spp., Trichomonas spp., Histomonas spp., Hexamita spp. and Toxoplasma gondii (Greiner and Ritchie, 1994; Martinez-Diaz et al., 2013; Gallo et al., 2014).

There is a dearth of studies on the parasites of ratites. In many cases, parasites are implicated as the cause of illness, but there are no studies that have demonstrated the presence of these parasites as a cause of pathology in emus. Often, disease is related to low levels of immunity, mixed infections, stress and malnutrition, but these animals commonly remain asymptomatic (Craig and Diamond, 1996).

The goal of the present study was to identify gastrointestinal parasites present in captive emus (Dromaius novaehollandiae) in Campos dos Goytacazes municipality, Brazil.

\section{Material and Methods}

Fresh feces were collected from 13 emus Dromaius novaehollandiae of both sexes belonging to a scientific breeding program of the Universidade Estadual do Norte Fluminense, Campos dos Goytacazes city, Rio de Janeiro state, Brazil. Samples were collected four times from each animal with intervals of three days between each collection. All animals were numbered to guarantee samples from all birds. The samples were identified, placed in isothermal containers on ice and later processed at the Núcleo de Pesquisas Avançadas em Parasitologia of the Veterinary Hospital of the Universidade Estadual do Norte Fluminense. For the morphological identification of trophozoites, cysts, oocysts and protozoal eggs in the feces of emus, centrifugation fecal flotation in Sheather's sugar solution (Sheather, 1923), direct fecal smears and direct smears after centrifugation were performed; the latter two techniques included staining of the samples with $2 \%$ Lugol's Iodine Solution. Samples that were positive for oocysts were mixed with a $2.5 \%$ potassium dichromate solution $\left(\mathrm{K}_{2} \mathrm{Cr}_{2} \mathrm{O}_{7}\right)$, passed through double gauze and aerated with an aquarium pump coupled to hoses to facilitate sporulation and then examined microscopically. A digital camera (Canon PowerShot A640, USA) coupled to a binocular microscope (Carl Zeiss, Germany) was used to photograph the parasites, and Zeiss AxioVision Sample Images Software was used for cyst, oocyst and egg measurements, which were recorded in micrometers $(\mu \mathrm{m})$.

For the molecular analysis, a pool of feces from each animal was made and the samples were processed by centrifugation with Sheather's sugar solution to concentrate and purify cyst (Fiuza et al., 2008). For DNA extraction, a DNeasy kit (Qiagen, Valencia, California) was used with reagents provided by the manufacturer. Modifications of the protocol included overnight incubation with proteinase $\mathrm{K}$ and elution with $100 \mathrm{ml}$ of buffer AE to increase the quantity of DNA recovered. For genotyping of Entamoeba spp., the 18S rRNA gene was amplified in a PCR reaction (Sukprasert et al., 2008). Primers ENTAM1 (5'-GTTGATCCTGCCAGTATTATATG-3') and ENTAM2 (5'-CACTATTGGAGCTGGAATTAC-3') were used to create a product of approximately $550 \mathrm{bp}$. For genotyping Giardia spp., the 18S rRNA gene was amplified in a nested PCR reaction (Appelbee et al., 2003; Hopkins et al., 1997). For the primary PCR assay, primers Gia2029 (5'-AAGTGTGGTGCAGACGGACTC-3') and Gia2150c (5'-CTGCTGCCGTCCTTGGATGT-3') were used to create a 497 bp product. This product was used in the secondary PCR assay with secondary primers RH11 (5'-CATCCGGTCGATCCTGCC-3') and RH4 (5'-AGTCGAACCCTGATTCTCCGCCAGG-3') to yield a 292 bp product. The PCR products were analyzed using electrophoresis in 1\% agarose gel stained with GelRed and immersed in 1x TAE buffer in a horizontal chamber. Bands were visualized using the Gel Logic 6000 PRO imaging system (Carestream ${ }^{\circledR}$, USA) after the electrophoretic run, and the fragment sizes were compared with a Low DNA Mass Ladder marker (Invitrogen ${ }^{\circledR}$, USA) using positive and negative controls that had been previously developed in the laboratory.

\section{Results}

Trophozoites and cysts of Entamoeba spp. (Figure 1A-F) and Giardia spp. (Figure 2A-B) were observed in the fecal samples analyzed with centrifugation with Sheather's sugar solution as well as in direct smears, in both stained and unstained samples. Using centrifugation fecal flotation, sporulated and non-sporulated oocysts of coccidia of the Eimeria genus (Figure 2C) and Isospora dromaii (Figure 2D) were observed and identified, as were eggs of the Ascaridida order (Figure 2E-F).

The trophozoites of Entamoeba sp. presented on average $44.8 \pm 6.3 \mu \mathrm{m}$ and $29.4 \pm 7.6 \mu \mathrm{m}(\mathrm{n}=3)$ of larger and smaller diameter. Uninucleate and multinucleate cysts (with at least six nuclei) measured on average $27.7 \pm 9,6$ and $25.6 \pm 8.9 \mu \mathrm{m}(\mathrm{n}=11)$ of larger and smaller diameter. Two cysts of Giardia spp. were observed in the feces of emus by the centrifugation fecal flotation technique measuring $11.7 \times 9.8 \mu \mathrm{m}$ and $10.8 \times 10.1 \mu \mathrm{m}$, in addition to a trophozoite with a diameter of $14.6 \times 12.2 \mu \mathrm{m}$.

The mean values of the largest and smallest diameters of the Eimeria spp. oocysts observed were $16.5 \pm 2.4 \mu \mathrm{m}$ and $16.0 \pm 2.6 \mu \mathrm{m}(\mathrm{n}=3)$, respectively. Oocysts of Isospora dromaii, averaging $21.6 \pm 2.9 \mu \mathrm{m}$ for the larger diameter and $19.8 \pm 2.7 \mu \mathrm{m}(\mathrm{n}=62)$ for the smaller diameter, were observed in the feces of the emus. In addition, several sporulated oocysts of Eimeria spp., characterized as ovoid to ellipsoid and double walled with rounded sporocysts, were observed, although other details, such as the sporozoite shape and absence or presence of Stieda and Substieda 
bodies, could not be ascertained. The sporulation time of both Isospora and Eimeria oocysts was 15-25 days at room temperature with forced aeration.

Fertile and infertile Ascaridia-type eggs found in the feces of the emus had larger and smaller mean diameter of

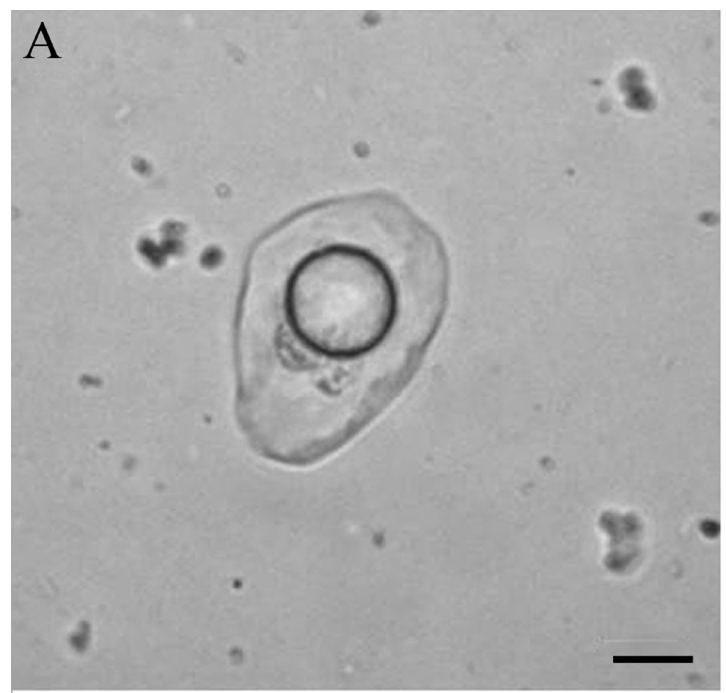

B
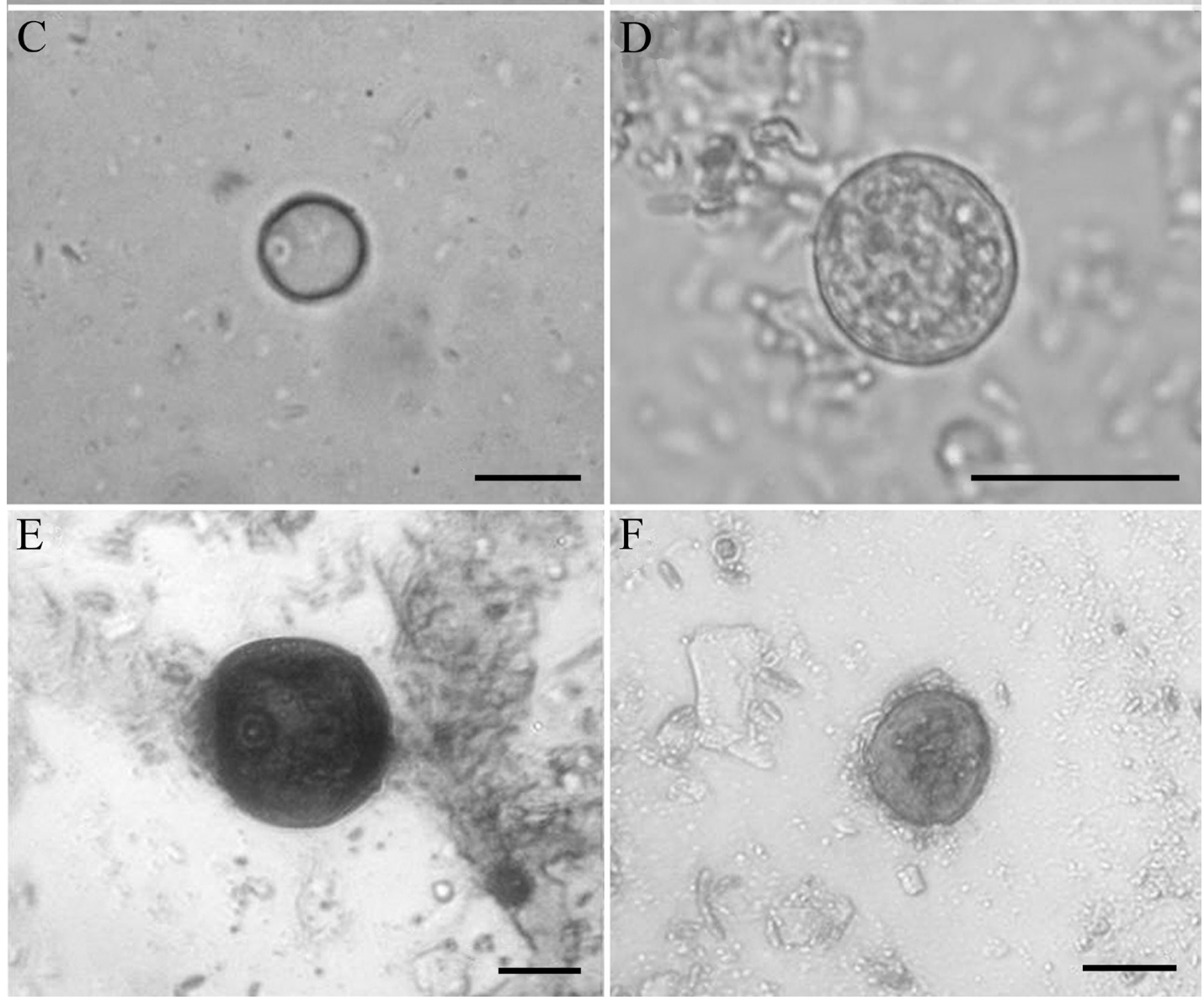

Figure 1. Photomicroscopy of Entamoeba sp. observed in emu feces, Dromaius novaehollandiae. In A and B, characteristic trophozoites with hyaline projections of the ectoplasm and very visible nucleus. In $\mathbf{C}$ cyst with a very visible nucleus and in D multinucleated cyst. $\mathbf{E}$ and $\mathbf{F}$ shows uninucleated and multinucleated cysts respectively stained by 2\% Lugol. Bars: $20 \mu \mathrm{m}$. 


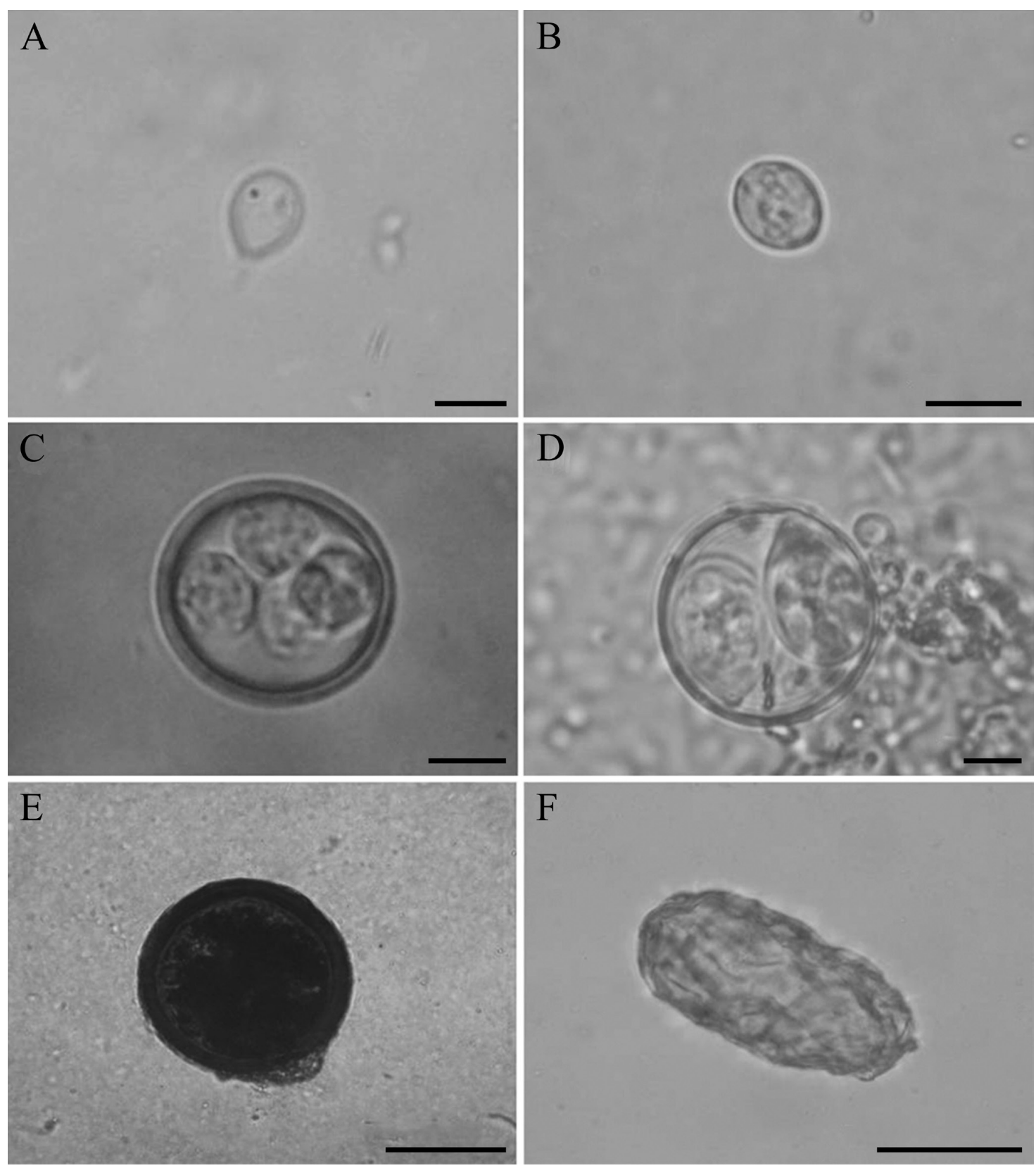

Figure 2. Trophozoite, cyst, oocysts of protozoa and nematode eggs found in fecal samples of emu, Dromaius novaehollandiae. Trophozoite (A) and cyst (B) of Giardia sp. Bars: $10 \mu \mathrm{m}$. Oocysts of Eimeria sp (C) and Isospora dromaii (D). Bars: $5 \mu \mathrm{m}$. Fertile (E) and infertile (F) Ascaridia-type eggs. Bars: $50 \mu \mathrm{m}$.

\section{Discussion}

The prevalence of gastrointestinal parasites can be high in places where living conditions and basic sanitation are minimal or nonexistent. Many parasites, such as protozoa of the genera Entamoeba and Giardia, helminths of the genus Ascaris and Trichuris, and many species of cestodes are transmitted through contaminated water or food, while other helminths are transmitted by larvae that are present in the soil (Neves, 2005).
In a study from Greece (Sotiraki et al., 2001), small diameter (10-15 $\mu \mathrm{m})$ uninucleate cysts of Entamoeba spp. were identified in the feces of ostriches; these cysts were much smaller than the uninucleate and multinucleate cysts observed in the emus feces of the present study. The cysts of E. gallinarum, described in bird feces, each have eight nuclei but are also smaller $(12-15 \mu \mathrm{m})$ than the cysts of Entamoeba spp. found in the emu feces, whereas $E$. coli cysts were measured at 10-33 $\mu \mathrm{m}$ (Tyzzer, 1920). In 2000 Martinez-Diaz et al. (2000) described Entamoeba sp. 
cysts with one nucleus in ostrich feces from Spain. Nearly $90 \%$ of the samples contained single-nucleus cysts with a mean diameter of $13.5 \mu \mathrm{m}(8-20 \mu \mathrm{m})$, whereas the trophozoites had a mean diameter of $19.9 \mu \mathrm{m}(8-35 \mu \mathrm{m})$. The mean diameters of the cysts and trophozoites of the present study were greater than those found by the previously cited author. Later in 2004, Ponce-Gordo et al. (2004) analyzed this parasite genetically and after finding differences in the sequence of RNA, they concluded be that a new species, naming it Entamoeba struthionis. In 2002, Ponce-Gordo et al. described cysts of eight nuclei in rheas Rhea americana of Europe that had a morphometry of $20 \mu \mathrm{m}$ on average, being smaller than those found in emus of the present study. The authors also suggested that this new species may infect hosts other than ratites. In rheas in Argentina, cysts of Entamoeba spp. containing one nucleus and others containing eight nuclei were found and identified as Entamoeba bovis-like and Entamoeba coli-like, respectively. The cysts found in the Argentine rheas had a range in diameter of 14-22 $\mu \mathrm{m}$ (Martinez-Diaz et al., 2013), again confirming that the diameters found in our study are greater than those described in other studies of ratites.

The authors Craig and Diamond (1996) cited the presence of Entamoeba sp. in ostriches, but in emus no reports were found. Once the presence of Entamoeba sp. in the emus feces was confirmed by the PCR technique and the cysts and trophozoites were characterized as larger than those found in other ratites we can hypothetically infer that Entamoeba sp. observed in the emus are different from the species already described in other birds including ratites. However, a molecular diagnosis with sequencing of the PCR product would be required before this hypothesis could be confirmed. Trophozoite size can vary depending on environmental conditions, but the same is not true for cysts (Neal, 1966). Further studies will need to be conducted, including experimental infection, cross-transmission and genetic analysis, to clarify the Entamoeba species for which emus are hosts.

In a study done on feces of the budgerigar Melopsittacus undulatus, Giardia trophozoites measuring $14 \mu \mathrm{m}$ in length and $6 \mu \mathrm{m}$ in width (Erlandsen and Bemrick, 1987) were morphologically distinct from previously described species, leading to the naming of a new species, $G$. psittaci. Trophozoites of $G$. duodenalis are approximately $10-12 \times 5-7 \mu \mathrm{m}$. These organisms have been isolated from humans, dogs, cats, guinea pigs, beavers, gerbils, birds, reptiles, sheep and cattle, and some of these animals are thought to act as reservoirs for human infection (Faubert, 1988). This trait has also been described in ostriches and emus (Craig and Diamond, 1996). Only two species of Giardia have been described in birds: G. ardeae, with trophozoites measuring $6.5 \times 10 \mu \mathrm{m}$ in diameter, and G. psittaci (Thompson, 2002). Further studies by these researchers describe the trophozoite sizes of the five species of this genus, in which the diameters range from 4 to $30 \mu \mathrm{m}$. None of those species have diameters that are comparable to those found in our study.

There are many reports of Cryptosporidium spp. infection in ostriches (Penrith et al., 1994; Penrith and
Burger, 1993) and a few in rheas (Ponce-Gordo et al., 2002). Cryptosporidium is a genus commonly found in ostrich feces (Huchzermeyer, 2002), but the same has not been demonstrated to occur in emus. In our study, no oocysts of this coccidian were found through any of the techniques performed.

In a study in Europe, in which 500 ostriches and a number of rheas were analyzed for the presence of ectoparasites and endoparasites, 29 species of parasites were identified, most of which were protozoans. Non-sporulated oocysts compatible with Isospora and Eimeria species were observed (Ponce-Gordo et al., 2002). At an ostrich breeding facility in Espírito Santo state, the presence of oocysts of the Isospora genus were identified (Batista et al., 2008). According to the author, the birds were in good health, with appropriate hygiene and husbandry, as were the emus in our study. Although coccidiosis has been described in ostriches and emus, infection with coccidia has not been confirmed to cause clinically important disease in ratites (Jensen, 1993), but has been reported to be primarily a disease of emu chicks (Jurajda, 2002).

Studies on the morphology of Isospora spp. and Eimeria spp. oocysts in ratites are scarce. Non-sporulated oocysts found in the feces of rheas and ostriches have been reported to measure 12-15 $\mu \mathrm{m}$ (Ponce-Gordo et al., 2002), but it is not possible to definitively identify the genus by oocyst size alone. As previously discussed, the number of Eimeria spp. oocysts found in this study was small, thereby preventing us from being able to fully describe these oocysts. In a study from Spain, feces were collected from ostriches in a zoo, and Eimeria spp. oocysts were identified (Pérez Cordón et al., 2008), however, the authors did not provide a morphological or morphometric description of the sporulated oocysts, preventing a comparison between our results and theirs. An analysis of feces from two emus in a zoo in Italy demonstrated the presence of coccidia, but the genus was not identified (Papini et al., 2012).

A study of ostrich feces described oocysts with shapes ranging from ellipsoid $(28 \times 22 \mu \mathrm{m})$ to spherical $(21 \times 21 \mu \mathrm{m})$ (Mushi et al., 1998). The researchers of this study were unable to induce sporulation, and thus the genus of this coccidian is unknown. The author reported that oocyst size in their study was similar to that of Eimeria tropicalis (Soulsby, 1987), which is spherical and subspherical, with dimensions of $19-24 \mu \mathrm{m} \times 18-23 \mu \mathrm{m}$; this species has been previously described in the ostrich. In another study, oocysts of Eimeria spp. with a mean size of $19 \times 23 \mu \mathrm{m}$ were found in $42 \%$ of the ostrich feces examined on Greek farms (Sotiraki et al., 2001). Oocysts of Eimeria spp. with a mean diameter of $26 \mu \mathrm{m} \times 23.7 \mu \mathrm{m}(24-28 \mu \mathrm{m}$ $\times 20-28 \mu \mathrm{m}$ ) were observed in fecal samples from rheas (Chang Reissig et al., 2001) which is larger than Isospora dromaii demonstrated in emus in the present study and described in a 2014 study (Santos Teixeira et al., 2014). In the same year, Isospora rheae was first described in the feces of rheas Rhea americana (Gallo et al., 2014). Oocysts of Isospora spp., which were identified in the feces of an ostrich from a Russian zoo and described as spherical 
with a diameter of $30.6 \mu \mathrm{m}$ and containing Stieda bodies, were designated Isospora struthionis (Yakimoff, 1940).

Baylisascaris spp. is a nematode of great clinical importance in ostriches. This parasite can be transmitted by eggs present in the feces of opossums and raccoons, causing serious damage to the central nervous system and great economic losses to the ostrich industry, since these eggs can remain viable in the soil for years (Nemejc and Lukesova, 2012). In Rio Grande do Sul state, where the feces of 452 ostriches were analyzed, 300 of those animals were found to be parasitized by eggs of Heterakis spp., Ascaridia spp., Capillaria spp., Hymenolepis spp., Codiostomum spp., Isospora spp. and Balantidium spp. (Mattos et al., 2011). Feces of 50 ostriches from Formiga, Minas Gerais state, were analyzed, and $10 \%$ were positive for Ascaridoidea eggs. Similar results were found in another study (Rosa, 2003) that reported that endoparasite eggs of the Ascaridoidea and Strongiloidea superfamilies were the most commonly observed parasites in ratite fecal flotation tests. Following the necropsy of an emu that presented with problems of locomotion and bilateral paralysis, an Ascaridoidea was identified in the cerebellum of the animal (Winterfield and Thacker 1978). In our study, eggs similar to Baylisascaris spp. were found in the feces of the emus. Previously, only a single study, in 1982, demonstrated the presence of Baylisascaris spp. in the feces of emus (Kazacos et al., 1982). Ascaris spp.-type eggs are prevalent throughout the world and are frequently demonstrated in the feces of domestic poultry as well as other animals (Rey, 2001). Infection by this nematode greatly impacts weight gain in affected animals, retarding growth by competing for nutrients with the host. Ascaris eggs remain viable in the environment for long periods of time, resulting in the infection and reinfection of animals. The presence primarily of protozoan parasites in the feces of the emus can be explained by the fact that these birds are prone to coprophagia, which contributes to infection with these parasites. Another reason for the development and maintenance of protozoan parasites is the local topography, which is flat and creates favorable sites for standing water (Dias et al., 2008). The emus studied here do not seem to be vulnerable to developing disease as a result of these infections, and no clinical signs were observed in any of the animals, which supports our assertion that some of these parasites may have no clinical significance.

Emus Dromaius novaehollandiae were enzootically parasitized by helminths characteristic of the Ascaridida order as well as by protozoa of the genera Entamoeba, Giardia, Isospora and imeria. Further analyses are needed to determine the implications of these infections for emus and the risk of infection in domestic animals, wildlife and humans.

\section{Acknowledgements}

The authors thank the research funding agency CAPES (Coordenação de perfeiçoamento de Pessoal de Nível Superior) for financial support.

\section{References}

APPELBEE, A.J., FREDERICK, L.M., HEITMAN, T.L. and OLSON, M.E., 2003. Prevalence and genotyping of Giardia duodenalis from beef calves in Alberta, Canada. Veterinary Parasitology, vol. 112, no. 4, pp. 289-294. http://dx.doi.org/10.1016/ S0304-4017(02)00422-3. PMid:12623208.

BATISTA, A.M.B., PEREIRA, M.A.V.C. and VITA, G.F., 2008. Intestinal parasitism on ostriches (Struthio camelus australis Linnaeus, 1786) from South Region of Espírito Santo State, in 2006. Revista Portuguesa de Ciências Veterinárias, vol. 103, no. 1 , pp. 189-193.

CHANG REISSIG, E., OLAECHEA, F. and ROBLES, C.A., 2001. Parasitological findings of lesser rhea, Pterocnemia pennata (D'orbigy) in faeces from northern patagonian, Argentina. Archivos de Medicina Veterinaria, vol. 33, no. 2, pp. 247-251. http://dx.doi. org/10.4067/S0301-732X2001000200014.

CRAIG, T.M. and DIAMOND, P.L., 1996. Parasites of Ratites. In: T.N. Tully and S.N. Shane, eds. Ratite Management, Medicine and surgery. Florida: Krieger Publishing Company, pp. 115- 126.

DAVIES, S.J.J.F., 1976. The natural history of the emu in comparison with that of other ratites. In: H.J. FRITH and J.H. CALABY, eds. The 16th international ornithological congress. Canberra: Australian Academy of Science, pp. 109-120.

DIAS, G.M.F., BEVILACQUA, P.D., BASTOS, R.K.X., OLIVEIRA, A.A. and CAMPOS, G.M.M., 2008. Giardia spp. and Cryptosporidium spp. in a fresh water supply source contaminated with human and animal excreta and waste water. Arquivo Brasileiro de Medicina Veterinária e Zootecnia, vol. 60, no. 6, pp. 1291-1300. http://dx.doi.org/10.1590/S010209352008000600001.

ERLANDSEN, S.L. and BEMRICK, W.J., 1987. SEM evidence for a new species, Giardia psittaci. The Journal of Parasitology, vol. 73, no. 3, pp. 623-629. http://dx.doi.org/10.2307/3282146. PMid:3598809.

FAUBERT, G.M., 1988. Evidence that giardiasis is a zoonosis. Parasitology Today, vol. 4, no. 3, pp. 66-68. http://dx.doi. org/10.1016/0169-4758(88)90197-4. PMid:15463044.

FIUZA, V.R., COSENDEY, R.I. and OLIVEIRA, F.C., 2008. Criptosporidiose suína associada aos sistemas de produção no Estado do Rio de Janeiro. Revista Brasileira de Parasitologia Veterinária, vol. 17, Suppl. 1, pp. 224-229. PMid:20059853.

GALLO, S.S., EDERLI, N.B., BERTO, B.P. and OLIVEIRA, F.C., 2014. A new coccidian, Isospora rheae sp. nov. (Apicomplexa, Eimeriidae), from Rhea americana (Aves, Rheidae) from South America. International Journal for Parasitology. Parasites and Wildlife, vol. 3, no. 3, pp. 236-238. http://dx.doi.org/10.1016/j. ijppaw.2014.07.002. PMid:25426418.

GREINER, E.C. and RITCHIE, B.W. 1994. Parasites. In: B.W. RITCHIE, G.L. HARRISON, L.R. HARRISON, eds. Avian Medicine: Principles and Application. Lake Worth: Wingers Publishing, pp. 1014-1019.

HOPKINS, R.M., MELONI, B.P., GROTH, D.M., WETHERALL, J.D., REYNOLDSON, J.A. and THOMPSON, R.C., 1997. Ribosomal RNA sequencing reveals differences between the genotypes of Giardia isolates recovered from humans and dogs living in the same locality. The Journal of Parasitology, vol. 83, no. 1, pp. 44-51. http://dx.doi.org/10.2307/3284315. PMid:9057695. 
HUCHZERMEYER, F.W., 2002. Diseases of farmed crocodiles and ostriches. Revue Scientifique et Technique, vol. 21, no. 2, pp. 265-276. http://dx.doi.org/10.20506/rst.21.2.1334. PMid:11974614.

JENSEN, J.M. 1993. Infection and parasitic diseases of ratites. In: M.E. Fowler, ed. Zoo and Wild Animal Medicine, 3rd ed. Philadelphia: Saunders WB Company. 617 p.

JURAJDA, V. 2002. Chov a nemoci pštrosů. 1st ed. Brno: Veterinární a farmaceutická univerzita, 92 p.

KAZACOS, K.R., WINTERFIELD, R.W. and THACKER, H.L., 1982. Etiology and epidemiology of verminous encephalitis in an emu. Avian Diseases, vol. 26, no. 2, pp. 389-391. http:// dx.doi.org/10.2307/1590109. PMid:7103894.

MARTÍNEZ-DÍAZ, R.A., HERRERA, S., CASTRO, A. and PONCE, F., 2000. Entamoeba sp. (Sarcomastigophora: Endamoebidae) from ostriches (Struthio camelus) (Aves: Struthionidae). Veterinary Parasitology, vol. 92, no. 3, pp. 173-179. http://dx.doi.org/10.1016/ S0304-4017(00)00314-9. PMid:10962154.

MARTINEZ-DIAZ, R.A., MARTELLA, M.B., NAVARRO, J.L. and PONCE-GORDO, F., 2013. Gastrointestinal parasites in greater rheas (Rhea americana) and lesser rheas (Rhea pennata) from Argentina. Veterinary Parasitology, vol. 194, no. 1, pp. 75-78. http://dx.doi.org/10.1016/j.vetpar.2012.12.021. PMid:23305970.

MATTOS, M.J.T., RIBEIRO, V.S. and MARQUES, S.M.T., 2011. Parasitismo gastrintestinal e aspectos do manejo de avestruzes (Struthio camelus) de pequenas propriedades do Rio Grande do Sul, Brasil. Revista Veterinária em Foco, vol. 8, no. 2, pp. 143-151.

MUSHI, E.Z., ISA, J.F., CHABO, R.G., BINTA, M.G., KAPAATA, R.W., NDEBELE, R.T. and CHAKALISA, K.C., 1998. Coccidia oocysts in the faeces of farmed ostrich (Struthio camelus) chicks in Botswana. The Onderstepoort Journal of Veterinary Research, vol. 65 , no. 4 , pp. 281-284. PMid:10192840.

NEAL, R.A., 1966. Experimental studies on Entamoeba with reference to speciation. Advances in Parasitology, vol. 4, pp. 1-51. PMid:4899987.

NEMEJC, K. and LUKESOVA, D., 2012. Parasite Fauna of Ostriches, Emus and Rheas. Agricultura Tropica et Subtropica, vol. 45, no. 1, pp. 45-50. http://dx.doi.org/10.2478/v10295-012-0007-6.

NEVES, D.P., 2005. Parasitologia Humana. 11 th ed. São Paulo: Atheneu, $494 \mathrm{p}$.

PAPINI, R., GIRIVETTO, M., MARANGI, M., MANCIANTI, F. and GIANGASPERO, A., 2012. Endoparasite Infections in Pet and Zoo Birds in Italy. The Scientific World Journal, vol. 2012, pp. 1-9. http://dx.doi.org/10.1100/2012/253127. PMid:22536128.

PENRITH, M.L., BEZUIDENHOUT, A.J., BURGER, W.P. and PUTTERILL, J.F., 1994. Evidence for cryptosporidial infection as a cause of prolapse of the phallus and cloaca in ostrich chicks (Struthio camelus). The Onderstepoort Journal of Veterinary Research, vol. 61, no. 4, pp. 283-289. PMid:7501359.

PENRITH, M.L. and BURGER, W.P., 1993. A Cryptosporidium sp. in an ostrich. Journal of the South African Veterinary Association, vol. 64, no. 2, pp. 60-61. PMid:8410943.

PÉREZ CORDÓN, G., HITOS PRADOS, A., ROMERO, D., SÁNCHEZ MORENO, M., PONTES, A., OSUNA, A. and ROSALES, M.J., 2008. Intestinal parasitism in the animals zoological garden "Peña Escrita" (Almuñecar, Spain). Veterinary Parasitology, vol. 156, no. 3-4, pp. 302-309. http://dx.doi. org/10.1016/j.vetpar.2008.05.023. PMid:18639383.
PONCE GORDO, F., HERRERA, S., CASTRO, A.T., GARCÍA DURÁN, B. and MARTÍNEZ DÍAZ, R.A., 2002. Parasites from farmed ostriches (Struthio camelus) and rheas (Rhea americana) in Europe. Veterinary Parasitology, vol. 107, no. 1-2, pp. 137-160. http://dx.doi.org/10.1016/S0304-4017(02)00104-8. PMid:12072221.

PONCE-GORDO, F., MARTINEZ DIAZ, R.A. and HERRERA, S., 2004. Entamoeba struthionis n.sp. (Sarcomastigophora: Endamoebidae) from ostriches (Struthio camelus). Veterinary Parasitology, vol. 119, no. 4, pp. 327-335. http://dx.doi.org/10.1016/j. vetpar.2003.10.022. PMid:15154597.

REY, L., 2001. Parasitologia e doenças parasitárias do homem nas Américas e na África. 3rd ed. Rio de Janeiro: Guanabara Koogam, $856 \mathrm{p}$.

ROSA, F.G.D.I., 2003. Apostila de criação de avestruzes. São Paulo: Struthio Consult, $159 \mathrm{p}$.

SHEATHER, A.L., 1923. The detection of intestinal protozoa and mange parasites by a flotation technique. The Journal of Comparative Pathology and Therapeutics, vol. 36, pp. 266-275. http://dx.doi.org/10.1016/S0368-1742(23)80052-2.

SILVANOSE, C.D., SAMOUR, J.H., NALDO, J.L. and BAILEY, T.A., 1998. Oro-pharyngeal protozoa in captive bustards: clinical and pathological considerations. Avian Pathology, vol. 27, no. 5, pp. 526-530. http://dx.doi.org/10.1080/03079459808419378. PMid: 18484038.

SOTIRAKI, S.T., GEORGIADES, G., ANTONIADOUSOTIRIADOU, K. and HIMONAS, C.A., 2001. Gastrointestinal parasites in ostriches (Struthio camelus). The Veterinary Record, vol. 148, no. 3, pp. 84-86. http://dx.doi.org/10.1136/vr.148.3.84. PMid:12503598.

SOULSBY, E.J.L. 1987. Parasitología y enfermidades parasitárias. 7th ed. México: Interamericana. $823 \mathrm{p}$

SUKPRASERT, S., RATTAPRASERT, P., HAMZAH, Z., SHIPIN, O.V. and CHAVALITSHEWINKOON-PETMITR, P., 2008. PCR detection of Entamoeba spp from surface and waste water samples using genus-specific primers. The Southeast Asian Journal of Tropical Medicine and Public Health, vol. 39, no. 1, pp. 6-9.

SANTOS TEIXEIRA, C., GALLO, S.S., EDERLI, N.B., BERTO, B.P. and DE OLIVEIRA, F.C., 2014. Isospora dromaii n. sp. (Apicomplexa, Eimeriidae) isolated from emus, Dromaius novaehollandiae (Casuariiformes, Casuariidae). Parasitology Research, vol. 113, no. 11, pp. 3953-3955. http://dx.doi.org/10.1007/ s00436-014-4059-6. PMid:25195056.

THOMPSON, R.C.A. 2002. Towards a better understanding of host specificity and the transmission of Giardia: The impact of Molecular epidemiology. In: B.E. Olson, M.E. Olson and P.M. Wallis, eds. Giardia: The Cosmopolitan Parasite. Wallingford: CAB International, pp. 55-69. http://dx.doi.org/10.1079/97808 51996127.0055

TYZZER, E.E., 1920. Amoebae of the caeca of the common fowl and of the turkey - Entamoeba gallinarum, sp. n. and Pygolimax gregariniformis, gen. et spec. nov. The Journal of Medical Research, vol. 41, no. 2, pp. 199-210. PMid:19972500.

WINTERFIELD, R.W. and THACKER, E.H.L., 1978. Verminous encephalitis in the emu. Avian Diseases, vol. 22, no. 2, pp. 336339. http://dx.doi.org/10.2307/1589546. PMid:567056.

YAKIMOFF, W.L., 1940. Isospora struthionis n. sp., coccidie de l'autruche africaine. Annates de Ia Societe beige de Medecine Tropicale, vol. 20, pp. 137-138. 